\title{
Perancangan Aplikasi Berbasis Desktop Dengan Microsoft Visual Basic (Studi Kasus: Aplikasi Absensi Anak Magang 1.0)
}

\author{
Mohammad Syamsul Azis ${ }^{1}$, Lukmanul Hakim² ${ }^{2}$, Walim \\ 1STMIK Nusa Mandiri Jakarta \\ e-mail: mohammad.myz@bsi.ac.id \\ 2Universitas Bina Sarana Informatika \\ e-mail: lukmanul.luh@bsi.ac.id \\ ${ }^{3}$ Universitas Bina Sarana Informatika \\ e-mail: walim.wam@bsi.ac.id
}

\begin{abstract}
Abstrak
Magang merupakan kegiatan wajib bagi mahasiswa tingkat akhir pada perkuliahan program diploma tiga. Kebijakan di lingkungan Universitas Bina Sarana Informatika, kegiatan magang dilakukan pada semester lima. Mengingat jumlah mahasiswa yang terlibat banyak dan kegiatan magang dilakukan untuk jangka waktu lama yaitu sekitar tiga sampai enam bulan maka kegiatan magang perlu dicacat dengan cermat melalui suatu aplikasi. Abang 1.0 singkatan dari Absensi Anak Magang generasi pertama. Aplikasi ini dibuat dengan Microsoft Visual Basic 6.0. Tujuan aplikasi ini adalah untuk mencatat kehadiran, kegiatan, agenda dan aktivitas-aktivitas lainnya yang dilakukan oleh mahasiswa selama magang pada suatu organisasi baik di perusahaan maupun instansi pemerintah. Metode yang digunakan untuk merancang aplikasi ini adalah dengan metode waterfall. Metode ini diawali dengan tahap analisis, desain, pengodean, pengujian dan pemeliharaan. Aplikasi Abang 1.0 telah diuji coba pada mahasiswa magang Universitas Bina Sarana Informatika di Kampus Karawang dan Kampus Cikampek selama dua semester, hasilnya menunjukkan bahwa pelaporan aplikasi Abang 1.0 lebih efektif dan efisien daripada cara manual berbasis kertas.
\end{abstract}

Kata kunci: Perancangan Aplikasi, Aplikasi Berbasis Desktop, Visual Basic, Abang 1.0

\begin{abstract}
Internships are a mandatory activity for final year students in a three-year diploma program. Policy at the University of Bina Sarana Informatika, internships are carried out in the fifth semester. Because the number of students involved is very large and apprenticeship activities are carried out for a long period of time which is around three to six months, the apprenticeship activities need to be carefully disabled through an application. Abang 1.0 stands for first generation apprenticeship application. This application was created with Microsoft Visual Basic 6.0. Created with the aim to record attendance, activities, write the agenda and activities carried out by students who are apprenticing to an organization both in companies and government agencies. The waterfall method is used to design this application. This method begins with the analysis, design, coding, testing and maintenance stages. The Abang 1.0 application has been tested on internship students at Bina Sarana Informatika University in the Karawang Campus and Cikampek Campus for two semesters. As a result, the apprenticeship reports with the Abang 1.0 application are more effective and efficient than the paper-based manual method.
\end{abstract}

Keywords: Application Design, Desktop-Based Applications, Visual Basic, Abang 1.0 


\section{Pendahuluan \\ Latar belakang masalah}

Magang merupakan kegiatan wajib bagi para mahasiswa semester lima di semua program studi diploma tiga di lingkungan Universitas Bina Sarana Informatika (BPMA-UBSI, 2018). Magang dapat didefinisikan sebagai kegiatan akademis yang bersifat praktek kerja lapangan untuk menunjang pengetahuan mahasiswa dalam mengenal dunia kerja sesuai dengan pengetahuan yang dipelajarinya selama kuliah (Mufida, Saragi, \& Siahaan, 2017). Magang dapat dilakukan di internal UBSI maupun di perusahaan swasta atau instansi pemerintah. Jangka waktu magang sedikitnya tiga bulan dan paling lama enam bulan. Selama magang mahasiswa berinteraksi langsung dengan sistem yang berjalan di organisasi tempat magang. Dengan begitu diharapkan mahasiswa mendapatkan pengetahuan empiris dan pengalaman bekerja.

Magang bermanfaat untuk meningkatkan kompetensi mahasiswa yaitu berupa peningkatan keterampilan dan etika dalam bekerja (Wijaya, 2019). Apabila dikaitkan dengan tugas akhir, magang adalah sebagai cara mahasiswa mendapatkan data awal untuk penyusunan tugas akhir. Magang di perusahaan atau instansi pemerintah merupakan penelitian pendahuluan bagi penyusunan proposal penelitian. Dengan melakukan magang mahasiswa dapat mengetahui dan memahami sistem yang sedang berjalan. Tentunya pada sistem yang sedang berjalan tersebut terdapat permasalahan atau kekurangan, keterbatasan sistem. Inilah yang kemudian menjadi titik awal atau masalah penelitian (research gap). Berangkat dari masalah aktual tersebut kemudian mahasiswa membuat suatu rumusan masalah penelitian dan pertanyaan penelitian yang akan dicari tahu jawabannya melalui penelitian selama sekitar enam bulan di semester akhir.

Pada program studi diploma Sistem Informasi dan Sistem Informasi Akuntansi, tugas akhir mahasiswa berupa pembuatan aplikasi komputer untuk menjawab permasalahan di lokasi magangnya tersebut. Diharapkan kegiatan magang dapat memberikan usulan solusi berupa aplikasi komputer bagi organisasi tempat magang dan bagi mahasiswa adalah pengalaman akademis berpikir ilmiah dan menciptakan aplikasi komputer berdasarkan permasalahan riil.

Kegiatan mahasiswa selama magang berbeda-beda. Sebagian besar bergantung pada kebijakan organisasi tempat magang dan terutama kebijakan dari supervisor atau pembimbing langsung di lokasi magang yang memberikan instruksi dan kewenangan-kewenangan. Mengingat jumlah mahasiswa yang magang banyak dan durasi waktu cukup lama yaitu sekitar tiga sampai enam bulan yang jika dalam satuan hari berarti selama $100-150$ hari kerja, maka diperlukan pencatatan aktivitas mahasiswa selama magang. Pencatatan ini diperlukan untuk monitoring selama magang dan utamanya sebagai instrumen untuk evaluasi. Umummnya pencatatan ini dilakukan secara manual secara paperbased. Mahasiswa magang diminta mengisi lembaran formulir yang kemudian diverifikasi oleh supervisor magang. Cara-cara seperti ini sudah berlangsung hampir dua dekade terakhir. Berdasarkan wawancara dengan sepuluh orang supervisor magang dan dosen pembimbing, cara pelaporan manual berbasis kertas memiliki banyak kekurangan, yaitu :

a. data kehadiran jam masuk atau jam pulang pada kertas bisa dimanipulasi, tidak akurat sebagaimana kondisi aktual

b. membutuhkan waktu yang lebih lama untuk menganalisis data tertulis, jika jumlah mahasiswa magang banyak

c. ada resiko kehilangan data akibat lembar formulir hilang

d. menggunakan media ketas yang tidak ramah lingkungan

e. diperlukan biaya kertas dan biaya cetak, sehingga tidak ekonomis

f. laporan berupa print out yang akan memakan ruangan, apabila jumlah laporan banyak, dalam hal ini tidak praktis

Dengan demikian administrasi magang secara manual membuat proses magang menjadi tidak efisien (Purwitasari, 2015). Berdasarkan permasalahan tersebut, diperlukan solusi yang lebih efektif dan efisien berbasis teknologi sistem informasi yang dapat membantu pengelolaan, penyelenggaraan hingga pelaporan kegiatan magang. Sistem komputerisasi dapat membantu menyelesaikan dan 
mempercepat suatu pembelajaran dan sistem administrasinya (Ayumida, 2018), hal ini tentunya akan berlaku juga untuk pengadministrasian magang mahasiswa. Penelitian ini bermaksud mendeskripsikan implementasi aplikasi berbasis desktop sebagai solusi pengadministrasian magang mahasiswa.

\section{Kajian literatur}

Aplikasi berasal dari kata application yaitu bentuk benda dari kata kerja to apply yang dalam Bahasa Indonesia berarti pengolah. Secara istilah, aplikasi komputer adalah suatu sub kelas perangkat lunak komputer menggunakan kemampuan komputer langsung untuk melakukan perintah yang dilakukan pengguna (Priana \& Fitriani, 2016). Pendapat lain, program atau aplikasi komputer adalah perangkat lunak atau software yang terdapat didalam komputer yang dapat melakukan berbagai tugas tertentu (Amri \& Sujarwadi, 2018).

Aplikasi desktop adalah aplikasi yang berjalan lokal dalam lingkungan desktop dan hanya dapat diakses oleh pengguna desktop Aplikasi desktop berbeda dengan aplikasi web yang dapat diakses dari manapun melalui jaringan. (Adiputra \& Mustofa, 2015). Pendapat lain menyatakan bahwa aplikasi desktop adalah aplikasi yang dapat berjalan secara sendiri atau independen dalam sistem desktop komputer atau laptop dan dapat menjalankan serangkaian aktivitas dengan diatur oleh pengguna (Liana, Sutardi, \& Muchlis, 2018). Visual Basic adalah bahasa pemrograman yang digunakan untuk membuat aplikasi Windows yang berbasis grafis (Novansyah, Sunardi, \& Ramadhan, 2015). Sementara itu, Microsoft Visual Basic adalah aplikasi yang dijalankan dengan menggunakan sistem operasi Windows yang juga merupakan hasil karya dari perusahaan Microsoft (Joanda, Priyandari, \& Zakaria, 2014). Program aplikasi ABANG 1.0 dibuat menggunakan bahasa pemrograman Microsoft Visual Basic. Pemilihan aplikasi tersebut dikarenakan bahasa pemrogramannya mempunyai visualisasi, bahasa pemrograman yang paling popular dan sederhana, serta mudah dalam pemahaman setiap sintaks-nya, dan dapat memanfaatkan hampir semua kemudahan serta kecanggihan yang disediakan sistem operasi Microsoft Windows (Riyanto, 2008). Solusi yang diusulkan
Berdasarkan kajian pustaka tersebut, solusi yang dusulkan adalah berupa apilikasi komputer berbasis desktop dengan nama Abang 1.0. Abang 1.0 singkatan dari Aplikasi Anak Magang generasi pertama. Aplikasi ini dibuat dengan Microsoft Visual Basic 6.0. Tujuan aplikasi ini adalah untuk mencatat kehadiran, kegiatan, agenda dan aktivitas-aktivitas lainnya yang dilakukan oleh mahasiswa selama magang pada suatu organisasi baik perusahaan maupun instansi pemerintah.

\section{Novelty}

Aplikasi berbasis desktop telah banyak dibuat dan dikembangkan dengan berbagai tujuan dan fungsi, namun aplikasi yang khusus untuk mahasiswa magang masih belum banyak dibuat. Oleh karena itu, novelty aplikasi ini adalah kekhususan fungsi aplikasi ini yang spesifik untuk mahasiswa magang.

\section{Metode Penelitian \\ Metode Pengembangan Perangkat Lunak} Metode pengembangan perangkat lunak adalah langkah yang dilalui oleh analis sistem dalam mengembangkan perangkat lunak yang ingin dibuat (Yulmaini \& Septina, 2008). Dalam pengembangan perangkat lunak ini, model yang digunakan adalah Water Fall. Menurut lan Sommerville tahapan model waterfall terdiri atas lima tahapan (Sommerville, 2004). Kelima tahapan tersebut seperti pada Gambar 1.

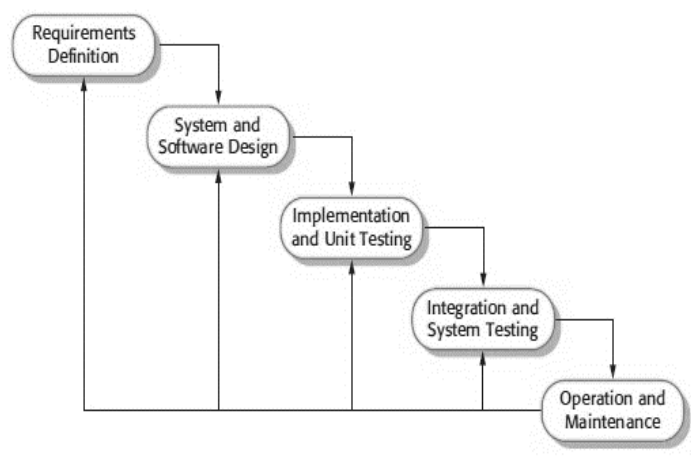

Gambar 1. Model Waterfall

Berikut adalah penjelasan dari tahapan-tahapan tersebut :

1. Requirement Analysis and Definition

Merupakan tahapan penetapan fitur, kendala dan tujuan sistem melalui wawancara dengan pengguna sistem. Semua hal tersebut akan ditetapkan secara rinci dan berfungsi sebagai spesifikasi sistem. 


\section{System and Software Design}

Dalam tahap ini akan dibentuk suatu arsitektur sistem berdasarkan persyaratan yang telah ditetapkan; mengidentifikasi dan menggambarkan abstraksi dasar sistem perangkat lunak; serta menggambarkan hubungan-hubungannya.

\section{Implementation and Unit Testing}

Pada tahap ini, hasil dari desain perangkat lunak akan direalisasikan sebagai satu set program atau unit program. Setiap unit akan diuji apakah sudah memenuhi spesifikasinya ataukah belum.

\section{Integration and System Testing}

Pada tahap ini, setiap unit program akan diintegrasikan satu sama lain dan diuji sebagai satu sistem yang utuh untuk memastikan apakah sistem sudah memenuhi persyaratan ataukah belum. Setelah itu sistem akan dikirim ke pengguna sistem.

\section{Operation and Maintenance}

Pada tahap ini, sistem diinstal dan mulai digunakan. Selain itu juga memperbaiki error yang tidak ditemukan pada tahap pembuatan. Dalam tahap ini juga dilakukan pengembangan sistem sepertipenambahan fitur dan fungsi baru

\section{Teknik Pengumpulan Data}

Pengumpulan data yang dilakukan pada penelitian yaitu :

1. Wawancara. Pada penelitian ini, wawancara dilakukan secara terbuka kepada perwakilan dosen pembimbing magang, supervisor magang mahasiswa dari perusahaan dan instasi pemerintah, dan mahasiswa yang telah menyelesaikan program magang.

2. Observasi. Pada penelitian ini, observasi dilakukan dengan pengamatan langsung terhadap dokumen-dokumen magang mahasiswa Universitas Bina Sarana Informatika Kampus Karawang dan Kampus Cikampek.

3. Studi Pustaka. Studi pustaka pada penelitian ini yaitu melakukan kajian terhadap jurnal ilmiah, buku teks, dan artikel ilmiah terkait perancangan aplikasi, aplikasi berbasis desktop dan visual basic 6.0 .

\section{Hasil dan Pembahasan}

Metode Waterfall digunakan dalam merancang aplikasi Abang 1.0 yang terdiri dari 5 tahapan, sebagai berikut:

\subsection{Tahap Requirement Analysis and \\ Definition.}

Pada tahap ini dilakukan wawancara mendalam terhadap ketua program studi sistem informasi dan ketua program studi sistem informasi akuntansi Kampus UBSI PSDKU Karawang, perwakilan dosen pembimbing magang sebanyak dua orang, perwakilan mahasiswa yang pernah magang sebanyak tiga orang dan dua orang supervisor dari perusahaan/instasi temapat mahasiswa magang. Tujuan wawancara ini adalah untuk mengetahui tujuan, peraturan, proses, dan luaran kegiatan magang mahasiswa serta kendala-kendala yang sering dialami oleh pihak-pihak tersebut. Informasi ini menjadi dasar penentuan fiturfitur di aplikasi Abang 1.0.

Setelah wawancara dengan stakeholders, selanjutnya observasi pada sistem yang sedang berjalan. Semua dokumen terkait magang mahasiswa pada periode sebelumnya dilihat, dicermati, dan dikategorisasikan, kemudian diambil kesimpulan yaitu pertama, berupa diagram alir proses magang mahasiswa dari awal sampai akhir dan kedua dibuat daftar fitur yang akan dibuat pada aplikasi Abang 1.0.

\subsection{Tahap System and Software Design}

Tahapan ini terdiri dari tiga kegiatan, yaitu Pertama, merancangan antarmuka; Kedua, merancang basis data, yang terdiri dari pembuatan Entity Relationship Diagram (ERD), pembuatan Logical Record Structure (LRS), dan pembuatan Flowchart. Ketiga, mengimplementasikan antarmuka. Secara rinci dijabarkan sebagai berikut:

1. Rancangan Antarmuka

Perancangan antar muka bertujuan untuk memberikan gambaran tentang aplikasi yang akan dibangun, sehingga akan mudah dalam mengimplementasikan aplikasi.

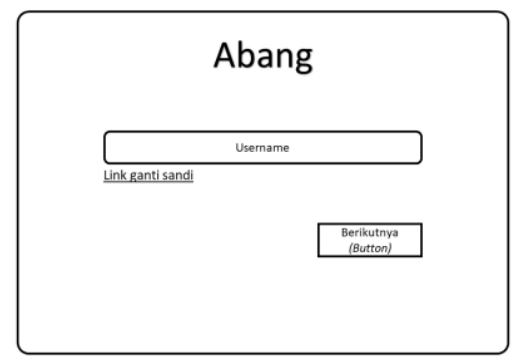

Gambar 2 Rancangan Antarmuka Log In Tahap Memasukkan Username 
Dan juga memudahkan pembuatan aplikasi yang user friendly. Rancangan aplikasi absensi anak magang adalah seperti pada Gambar 2.

Pada rancangan antar muka log in tahap memasukkan username terdiri dari kolom untuk mengisi nama pengguna, seperti pada Gambar 2. Selanjutnya, pengguna diminta memasukkan password, seperti pada Gambar 3.

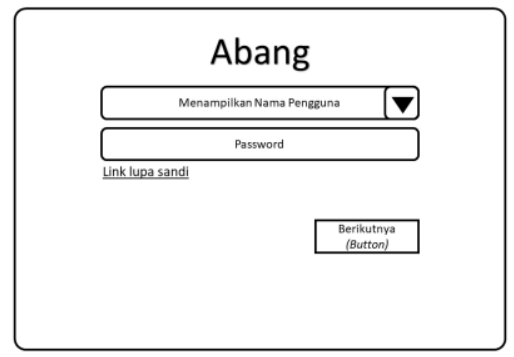

Gambar 3 Rancangan Antar Muka Log In Tahap Memasukkan Password

Setelah memasukkan password, user dapat melihat tampilan lengkap akun dengan menu utama tombol untuk menuliskan kegiatan, detail absensi, detail kegiatan yang telah di-entry, dan detail akun, seperti pada Gambar 4.

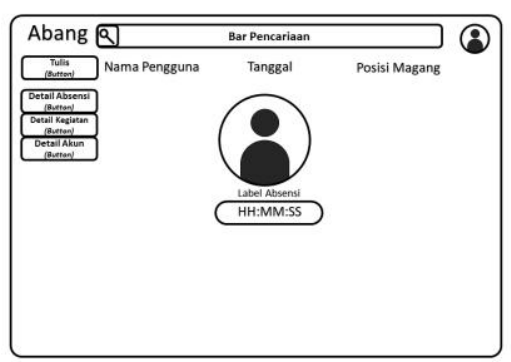

Gambar 4 Rancangan Antar Muka Absensi

Selain itu, pada rancangan antar muka absensi juga ditampilkan nama user, tanggal dan posisi divisi atau bagian dimana user magang di hari tersebut. Pada rancangan antar muka rekap absensi, terdapat informasi tambahan berupa tabel absensi yang menampilkan label informasi absensi masuk, absensi tengah, dan absensi keluar, seperti pada Gambar 5. Setiap tabel menampilkan detail pukul, menit dan detik user mengakses aplikasi. Hal ini sebagai kontrol kehadiran user di hari tersebut. Dari data ini kemudian dapat dimonitor kedisiplinan waktu pemilik akun, yaitu mahasiswa yang sedang magang.

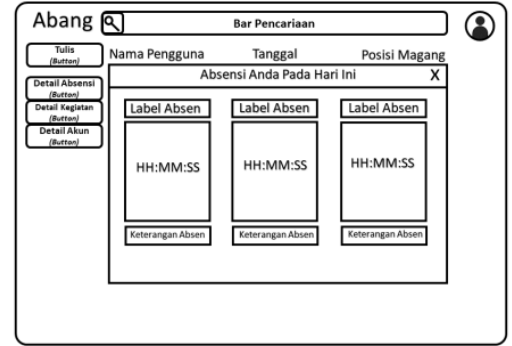

Gambar 5 Rancangan Antar Muka Rekap Absensi

Button "tulis" berfungsi untuk menginput kegiatan magang pada hari tertentu. Dengan mengklik button "tulis" maka akan muncul formulir isian kegiatan magang seperti pada Gambar 6. User dapat mengisi informasi lengkap aktivitas di hari tersebut. Informasi inilah kemudian yang akan terbaca oleh supervisor magang dan dosen pembimbing.

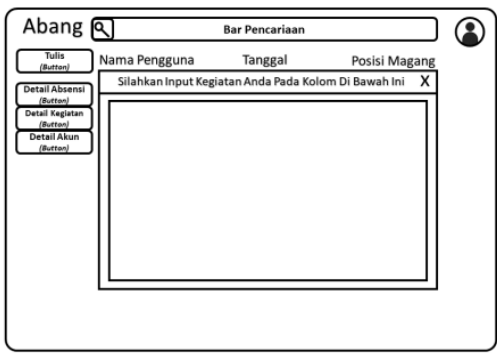

Gambar 6 Rancangan Antar Muka Input Kegiataan

Selanjutnya rancangan antar muka detail akun. Berisi akun, password, nama lengkap user, bagian yang menginformasikan posisi user, nomor telepon, dan foto user yang dapat diganti, seperti pada Gambar 7 .

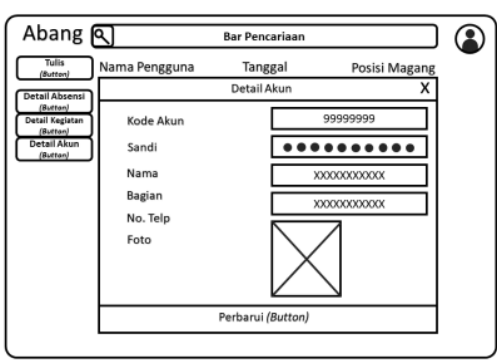

Gambar 7 Rancangan Antar Muka Detail Akun

2. Perancangan Basis Data

a. Entity Relationship Diagram (ERD)

Menurut Yuhendra, Entity Relationship Diagram (ERD) adalah bagian 
yang menunjukkan hubungan antara entity yang ada dalam sistem (Yuhendra \& Yulianto, 2015). Senada dengan itu, ERD adalah sebuah model data yang menggunakan beberapa notasi untuk menggambarkan data dalam hal entitas dan relasi yang digambarkan oleh data tersebut (Renatha, Satoto, \& Nurhayati, 2015). Pengertian ERD lainnya, ERD adalah suatu alat untuk mempresentasikan model data yang ada pada sistem dimana didalamnya terdapat entity dan relationship yang masing-masing dilengkapi dengan atributatribut yang mempresentasikan seluruh fakta dari dunia nyata yang digambarkan dengan lebih sistematis dengan menggunakan diagram (Astiti, 2015). ERD pada aplikasi Abang ini seperti pada Gambar 8. ERD pada aplikasi Abang 1.0 terdapat tiga entitas, yaitu absen, akun, dan sandi.

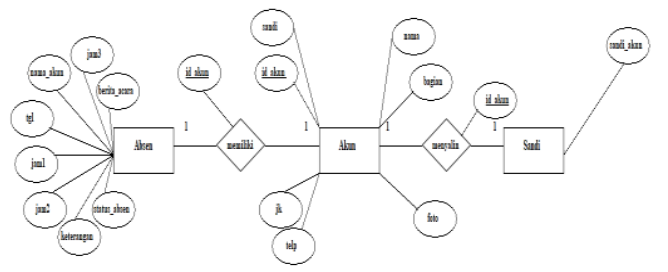

Gambar 8 ERD Aplikasi Abang 1.0

\section{b. Logical Record Structure (LRS)}

Menurut Dhanta "Logical Record Structure (LRS) adalah representasi dari struktur record-record pada tabel-tabel yang terbentuk dari hasil antar himpunan entitas. Menentukan kardinalitas, jumlah table dan foreign key" (Dhanta, 2009).LRS Aplikasi Abang 1.0 seperti pada Gambar 9 .

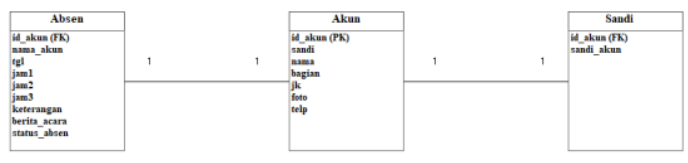

Gambar 9 LRS Aplikasi Abang 1.0

\section{c. Flowchart}

Menurut Kendall dan Kendall, "flowchart atau diagram alir data adalah gambaran proses-proses data, aliran data, dan simpanan data secara grafis dalam suatu sistem perusahaan"(Kendall \& Kendall, 2006). Flowchart Aplikasi Abang 1.0 seperti pada Gambar 10 dan 11 .

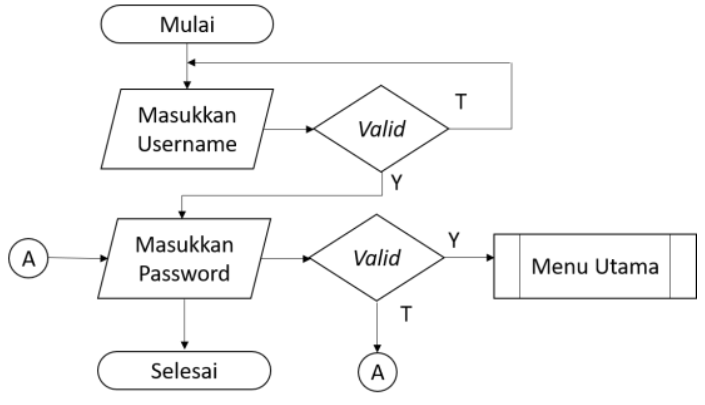

Gambar 10 Flowchart Log In

Flow chart log in dimulai dari user menginput username, jika data yang diinput valid maka berlajut ke proses selanjutnya, yaitu menginput password, jika data valid maka dapat masuk ke menu utama, seperti pada Gambar 10.

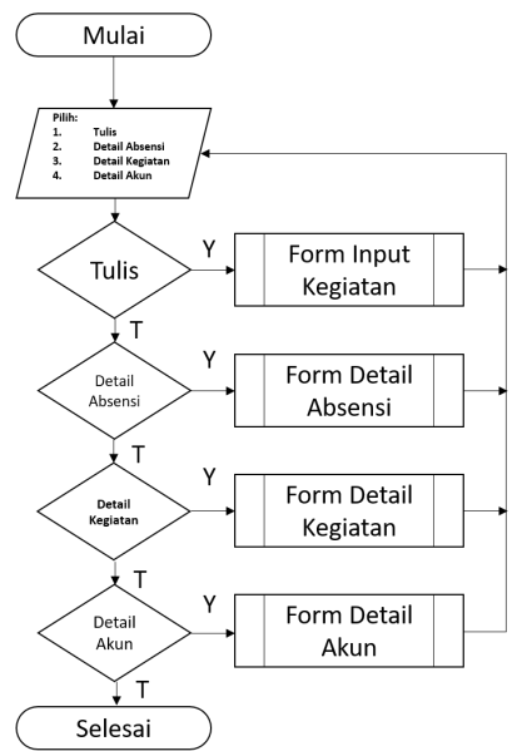

Gambar 11 Flowchart Menu Utama

Deskripsi skema flowchat program aplikasi abang:Langkah pertama program dijalankan dengan memulai login, setelah melakukan login terdapat menu utama yang menjadi pilihan diantaranya, menu Tulis, menu detail absensi, menu detail Kegiatan dan menu detail akun.

Ketika kita memilih menu tulis maka terdapat sebuah pilihan atau decision mau di pilih atau tidak? apabila program di jalan kan memilih tulis maka akan di proses ke form input kegiatan, ketika tridak maka kita bisa memilih yang menu selanjutnya dan ketika kita tidak memilih semua menu maka and /selesai. 


\subsection{Implementation and Unit Testing}

Tahap selanjutnya adalah implementasi dan menguji aplikasi. Berikut adalah implementasi antarmuka Aplikasi Abang 1.0.

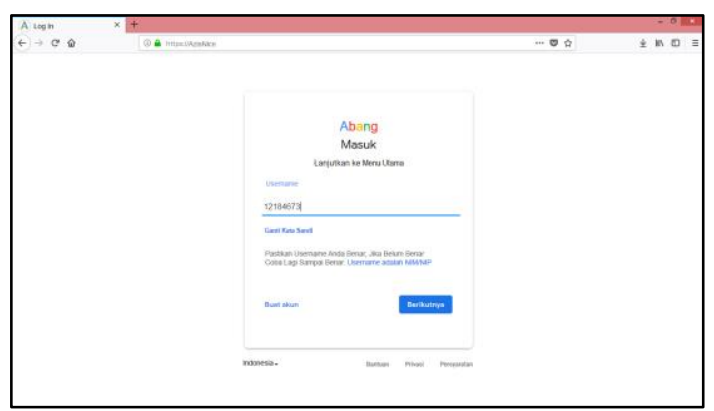

Gambar 12 Tampilan Log In Tahap

Memasukkan Username

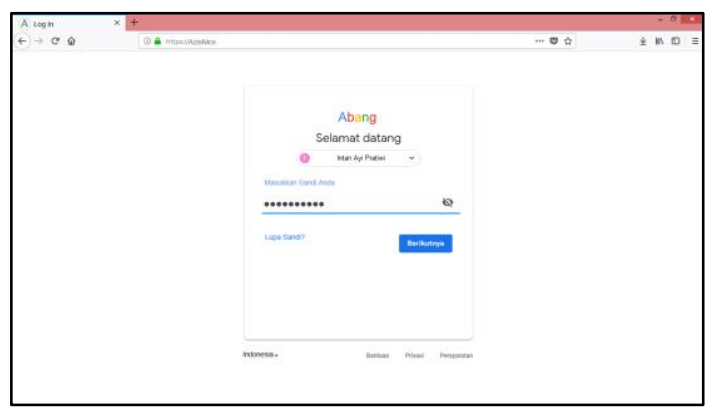

Gambar 13. Tampilan Log In Tahap Memasukkan Password

Deskripsi implementasi antarmuka bagian login, dimana di menu login ini user diwajibkan memasukan username yang sudah terdaftar dan dalam login ini memiliki 2 hak akses yang pertama sebagai login admin yang kedua sebagai user dimana user hanya bisa di daftarkan oleh admin yang merupakan dosen pembimbing magang.

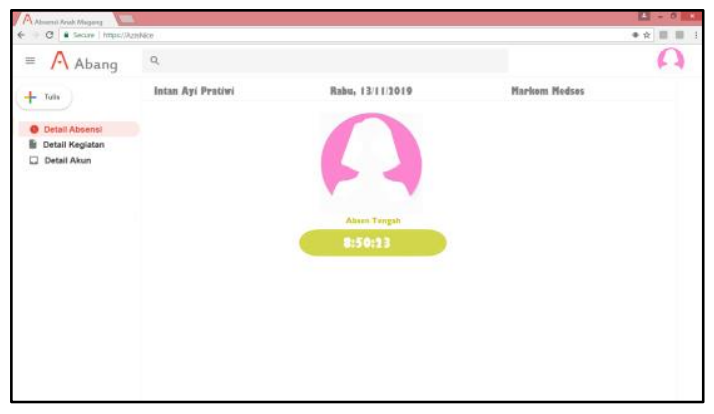

Gambar 14 Tampilan Absen
Deskripsi implementasi antarmuka bagian Menu utama, disini user bisa memilih beerapa pilihan yang ada di menu utama seperti menu Tulis, menu detail absensi, menu detail Kegiatan dan menu detail akun.

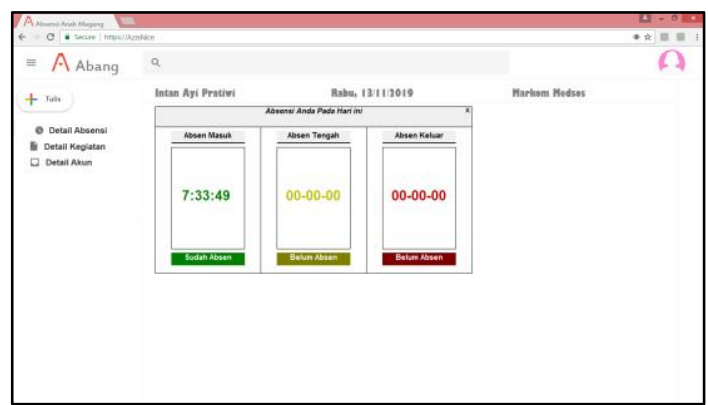

Gambar 15 Tampilan Rekap Absen

Deskripsi implementasi antarmuka bagian menu detail absensi, dimana user bisa melihat rekapan absensinya per satu hari.

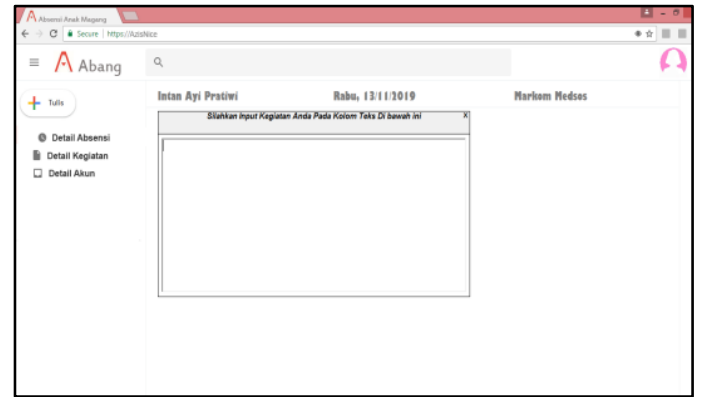

Gambar 16 Tampilan Input Kegiatan

Deskripsi implementasi antarmuka bagian menu tulis dimana di bagian menu ini user akan menginputkan data kegiatan .

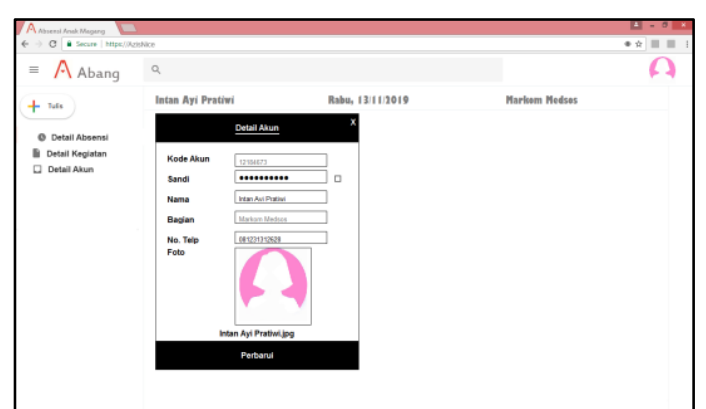

Gambar 17 Tampilan Detail Akun

Deskripsi implementasi antarmuka bagian menu detail akun dimana dalm menu ini user bisa mengupdate data dirinya.

Pada tahap ini diuji setiap fitur yang ditampilkan oleh aplikasi. Berdasarkan hasil pengujian, diperoleh kesimpulan bahwa Aplikas Abang 1.0 baru bisa mengakomodir 
kepentingan mahasiswa magang dan dosen pembimbing. User yang dikenal pada tahap awal ini adalah dosen pembimbing sebagai admin dan mahasiswa magang sebagai user. Versi 1.0 belum mengakomodir user untuk Ketua Program Studi yang dapat memantau langsung aktivitas mahasiwa diabawah binaanya dan user dari pihak perusahaan dan instansi. Namun demikian Abang 1.0 sudah layak digunakan pada tahap uji coba sistem yang terintegrasi.

\subsection{Integration and System Testing}

Aplikasi Abang 1.0 sudah siap digunakan. Aplikasi ini diujicobakan pada mahasiswa magang di Kampus UBSI Cikampek dan Karawang selama 2 semester. Aplikasi Abang 1.0 kemudian diintal di komputer desktop di lokasi magang. Setiap mahasiswa magang wajib menggunakan aplikasi ini selama periode magang, yaitu sekitar $3-6$ bulan. Pada akhir periode magang, dosen pembimbing sebagai admin menarik data proses magang mahasiswa bimbingannya untuk dianalisis. Laporan magang luaran Aplikasi Abang 1.0 dalam format file Microsoft Excel. Dengan demikian dosen pembimbing dapat dengan mudah mengolah data pada file tersebut.

Dari hasil wawancara dan observasi diketahui bahwa aplikasi ini telah dapat berfungsi dengan baik. Fitur-fitur yang disediakan telah sesuai dengan kebutuhan user yaitu mahasiswa magang dan dosen pembimbing. Namun demikian, menurut user, aplikasi ini masih dapat dikembangkan dan ditingkatkan fitur-fiturnya. Salah satunya adalah dengan meningkatkan dari aplikasi berbasis desktop menjadi aplikasi berbasis website atau bahkan berbasis Android sehingga lebif fleksibel.

\subsection{Operation and Maintenance}

Tahap uji coba telah dilakukan selama dua semester di dua kampus. Tahap selanjutnya adalah mengoperasikan secara luas disemua kampus Universitas Bina Sarana Informatika. Untuk mencapai tahap ini diperlukan persetujuan dari Pimpinan universitas. Apabila disetujui maka pihak universitas perlu mempersiapkan segala keperluan implementasi dan pemeliharaannya. Tim Pencipta masih melakukan persiapan-persiapan menuju tahap akhir ini, diantaranya adalah dengan terlebih dahulu mendaftarkan hak kekayaan intelektual (HKI) Aplikasi Abang 1.0.

\subsection{Manfaat Aplikasi Abang 1.0}

Setelah Aplikasi Abang 1.0 didesain, dibuat, dan diujicoba kemudian user dosen pembimbing dan user mahasiswa magang diwawancara untuk diambil suatu kesimpulan apakah aplikasi ini bermanfaat atau tidak. Berikut merupakan intisari manfaat yang disampaikan oleh responden:

1. Perekapan absensi dengan aplikasi berbasis dekstop ini dapat memudahkan anak magang dalam melakukan absensi secara digital, dan melakukan input kegiatan dengan mudah. Sementara itu, manfaat bagi instansi tempat magang dapat memudahkan dalam pengecekan data kehadiran dan data kegiatan per harinya.

2. Penggunaan aplikasi berbasis dekstop ini dapat melakukan pengolahan data rekam yang dilakukan dengan input data, mencetak data untuk dijadikan laporan, dimana semua data yang diperlukan disimpan dalam suatu database.

3. Aplikasi desktop ini dapat mengatasi masalah penambahan data yang identik dengan kertas yang menumpuk dan terkadang terjadi kehilangan karena terselip dan faktor lainnya.

\section{Kesimpulan}

Aplikasi Abang 1.0 merupakan aplikasi berbasis desktop yang berfungsi sebagai tool pencatatan kehadiran dan kegiatan serta pelaporan mahasiswa magang. Aplikasi ini dibuat dengan metode Water Fall dengan bantuan software Microsoft Visual Basic dan dapat diimplementasikan pada komputer dengan operating sistem Wimdows. Aplikasi ini dinilai lebih efisien dan efektif dibandingkan dengan metode konvensional berbasis kertas.

\section{Saran}

Pertama, pada versi selanjutnya, aplikasi ini dapat ditingkatkan menjadi berbasis website sehingga dapat diakses menggunakan komputer atau gawai manapun. Kedua, user bisa melakukan pendaftaran sendiri ke sistem tapi berdasrkan persetujuan dosen pembimbing.

\section{Referensi}

Adiputra, F., \& Mustofa, K. (2015). Purwarupa Framework Aplikasi Desktop Menggunakan Teknologi Web. Indonesian Journal of Computing 
and Cybernetics Systems, 9(1), 23-32.

Amri, I. F., \& Sujarwadi, A. (2018). Perancangan Program Aplikasi Manajemen Keuangan ( KAS ) Pondok Pesantren. Jurnal Informatika SIMANTIK, 3(2), 43-50.

Astiti, N. M. (2015). Analisa dan Perancangan Aplikasi Pembelajaran Matematika Berbasis Android. Konferensi Nasional Sistem dan Informatika 2015 STMIK STIKOM Bali, 9 - 10 Oktober 2015. Denpasar, Bali.

Ayumida, S. (2018). Aplikasi TASIBAR (Pendaftaran Siswa Baru) Pada SD Negeri Cikampek Selatan I-Karawang. Jurnal Interkom, 13(2), 21-30.

BPMA-UBSI. (2018).

PEDOMAN PENYUSUNAN PROPOSAL PRAKTIK KERJA LAPANGAN (PKL) UNIVERSITAS BINA SARANA INFORMATIKA. Jakarta: Badan Penjaminan Mutu \& Akreditasi, Universitas Bina Sarana Informatika.

Dhanta, R. (2009). Pengantar Ilmu Komputer. Surabaya: Penerbit Indah.

Joanda, A. D., Priyandari, Y., \& Zakaria, R. (2014). Perancangan Sistem Informasi Manajemen Layanan Jasa Teknologi dan Kerjasama di Lembaga DEF. Jurnal Sistem Informasi, 10(2), 94107.

Kendall, K. E., \& Kendall, J. E. (2006). Analisis dan Perancangan Sistem (Edisi Keli). Jakarta.: PT Indeks.

Liana, Sutardi, \& Muchlis, N. F. (2018). Aplikasi Enkripsi dan Deskripsi Data Menggunakan Tiny Encryption Algorithm (TEA) Berbasis Java. SemanTIK, 4(1), 39-48.

Mufida, K. M., Saragi, C. S. R., \& Siahaan, F. E. (2017). Clustering Dan Visualisasi Data Magang Mahasiswa Politeknik Negeri Batam. Prosiding SENTIA 2017 - Politeknik Negeri Malang, 9, 65-70.

Novansyah, A., Sunardi, H., \& Ramadhan, M. (2015). Sistem Informasi Pengolahan Zakat dan Infaq pada Masjid Agung Palembang. JURNAL INFORMATIKA GLOBAL, 6(1).

Priana, I., \& Fitriani, L. (2016). PERANCANGAN APLIKASI PERANGKAT LUNAK PENGELOLAAN DATA BANK SAMPAH DI PT . INPOWER KARYA MANDIRI GARUT. Jurnal Alogaritma
STTG, 14(2), 407-413.

Purwitasari, A. (2015). Sistem Informasi Pengelolaan Magang guna Mempermudah Proses Administrasi. Journal of Chemical Information and Modeling, 03(01), 01-06. https://doi.org/10.1017/CBO978110741 5324.004

Renatha, F. A., Satoto, K. I., \& Nurhayati, O. D. (2015). Perancangan dan Pengembangan Sistem Informasi Perpustakaan Berbasis Web (Studi Kasus Jurusan Sistem Komputer). Jurnal Teknologi Dan Sistem Komputer, 3(3), 343-353.

Riyanto, A. D. (2008). Membangun Aplikasi Alarm Menggunakan Visual Basic 6.0. Jurnal Telematika, 1(1), 34-43.

Sommerville, I. (2004). Software Engineering: Rekayasa Perangkat Lunak (Edisi 6). Jakarta: Erlangga.

Wijaya, N. I. (2019). Efektifitas Program Magang Mahasiswa Bersertifikasi (PMMB) Dalam Mendukung Tujuan Mata Kuliah Kerja Praktik (KP) di Universitas Hang Tuah. In Proceeding Indonesia Career Center Network Summit IV (pp. 82-89). Samarinda: Indonesia Career Center Network.

Yuhendra, \& Yulianto, R. E. (2015). Rekayasa Perangkat Lunak Pengolahan Data Distribusi ObatObatan Di Pt. Anugrah Pharmindo Lestari Berbasis Web. Momentum, 17(2), 68-75.

Yulmaini, \& Septina, N. (2008). Perangkat Pembelajaran Biologi Untuk Sekolah Menengah Umum ( Smu ). Seminar Nasional Informatika 2008 UPN "Veteran" Yogyakarta, 24 Mei 2008, (semnasIF), 279-288. 